\title{
José Santos Chocano
}

Forma parte este artículo de un conjunto de tres que acerca de Chocano, Eguren y Vallejo, aparecerán sucesivamente en nuestra Revista, bosquejando la figura de tres poetas nuestros que, en el siglo XX anduvieron por muy diversos caminos de poesía. Son ellos - tal vez si por su manera de expresión distinta y su sensibilidad orientada hacia mundos poéticos lejanos entre si- los tres poetas representativos del Perú contemporáneo.

Hablar de José Saríos Chocano es discurrir, entre el decorado de paisajes peruanos, acerca de las figuras literarias y de las formalidades métricas; qué conjuncién le imágenes y acentó nuevo dentro de combinación de modelos Jde versificaciónllifué sư poesía. Tuvo por escenario el llamado "modernismo": escuela americana que recogiera la resonancia de Walt Whitmann, ja musicalidad de José Asunción Silva y la elegante decadencia de Rubén, como pilares donde asentarse por espacio de 20 años. Whitman trajo un extraño sentido al verso. Fué unas veces trompəła de mesiánico llamado; otras apóstol de nacionalismo y las más maestro de rara facilidad rítmica. Silva hizo de la "sinfonía" antesala del verso y dividió su angustia en tres tiempos para el imponderable "Nocturno". Rubén - parnasiano y simbolista a la vez-intensificó al estudic de las formalidades métricas y como Mallarmé huyó del "Parnaso" para deleite de cisnes, de flores de loto, de princesas enamoradas y de cantilenas de fantasioso andar por el mundo de la imaginación. Simbólico en sus sugerencias, en el perfume de sus palabras que llamaban a la sensibilidad; fué parnasiano en descubrir el encanto del alejandrino - -siete más siete- que desde los tiempos de Lambert Le Tort no había alcanzado aquella excelsa lentitud que consiguió 
Dario; quien por otra parte combinó la ligereza del tetrasílabo con la entonación épica de los versos de "arte mayor". El modernismo fué un volver al artificio después de la disciplina científica de los "realistas" y "naturalistas", con una angustiosa búsqueda de la perfección y de la sonororidad, en un "ricorsi" de barroquismo y en una inmersión en la poesía de efecto, de fuegos artificiales, de falsas melancolías bien fabricadas y de llamado intenso al individualismo.

José Assunción Silva, voz lírica de Cundinamarca, moría -a los 31 años- en 1896, cuando Chocano iniciaba su carrera poética, dejando un camino por' el que transitarían españoles como Gabriel y Galán, Unamuno, Ruedas; y americanos como el propio Darío, como Gutiérrez Najera, como Herrera Reissing. Está Silva en el otro ángulo del modernismo. Su palabra es mera emoción y recuerdo. Persiste la nostalgia en la poesía "Nupcial"; en "Vejeces" hay siempre "la voz de las cosas". Chocano, que avanza en la escuela "modernista" tiene más bien un lenguaje fuerte, épico, apostólico, vibrante. Es el anti-Silva. Muchas veces recogió al poeta bogotano en el tema de sus composiciones: "Fué una noche toda llena de ilusiones, fué una noche toda llena de recuerdos..." que dice en la "Añoranza" de su libro "Alma América"; en otras imitó su deslizarse trémulo en el libre verso, mezclando los fundamentales dodecasílabos con los versos de cinco sílabas, de ocho o de dieciseis, como en su musical "Elegía del Organo":

\section{"Suena el órgano Puccinelli Converson}

suena el órgano en la iglesia solitaria, suena el órgano en el fondo de la noche; $\mathrm{y}$ hay un chorro de sonidos melodiosos en sus flautas, que comienzan blandamente... blandamente... como pasos en alfombras, como dedos que acarician, como sedas que se arrastran,

Y, de súbito se encrespan

$y$ se hinchan y rebraman, a manera de ancho río que sepulta en un lecho rocalloso, la solemne pesadumbre de sus aguas.....

Pero con todo, Chocano está frente a Silva, en su afán de señalar una intención, en la exuberancia de sus adjetivos, en la no confidencia de su poesía, dicha en la plaza pública y con ánimo de extraer los fuer. tes juegos selváticos y no el vago perfume de las orquídeas, colocadas 
al pie del balcón en la postrer noche desvelada del poeta neurótico. Cuando las sombras de los muertos se acercan a Chocano se confunden con las imágenes de Incas, Virreyes, Capitanes, damas que ofrecen espléndidas su amor, y se detienen en los salones luminosos multiplicándose "cuatrocientas veces" en los espejos; en tanto que las sombras de Silva van unidasi por "la' estepa solitaria", finas, lánguidas, con el frío de la "nada", de "las sábanas mortuorias", y se alejan enlazadas en las "noches de tristezas y de lágrimas"...

Rubén Darío, autobiográfíco nos dice que fué el poeta que "ayer no más decía el verso azul y la canción profana"; marcialmente expondría que sabe un "himno gigante y extraño"; y en otra parte entonará "cantos de vida y esperanza", por sobre la nostalgia de Verlaine y la aterciopelada estilización de todas "las margaritas", pero tiene siempre un dejo exotista y europeizante. Chocano cantará a América en su conjunción de lo español y lo indio, y aunque retórico y epidérmico, representará lo que inútilmente buscaban muchos poetas de su tiempo: la voz del Continente:

"Soy el cantor de Ämérica autóctono y salvaje..."

Chocano en "Los Caballos de los Conquistadores" superó las imágenes del Darío de "La Marcha Triunfal". Pero si aquel consiguió resonancỉa onomatopéyica, Rubén alcanzó una composición orquestada, en que la fuerza rítmica está sobre la persuasión de las imágenes evocadas... Biblloteca de Letras

Whitman fué el quelimpresionón más hondamente a Chocano. Pero en Whitman la palabra se torna enseñanza evangélica y alegría universal; hay trascendencia. En Chocano persevera el detalle, el sentimiento local, la idea de razas. Whitman camina hacia lo cósmico, Chocano marcha hacia las "tradiciones", en una cascada de símiles.

Chocano dentro de los modernistas, tiene un acento indudablemente propio, rebelde, en que no hay obsesivo cuidado de la perfección formal, sino la actitud romántica con que se iniciara en la épica acción cívica de la revolución antimilitarista del 94 . Buscaba la novedad de un ritmo jugoso en sus estrofas, y luego se dejaba arrebatar con el sonido de sus palabras:

"Confieso que, yo amo las pompas coloniales,

a las más finas cuerdas prefiero los metales:

tal doy con mis clarines imperativas dianas;

$y$, entonces, sactifico mis bellas baratijas, 
como los viejos nobles que echaban sus sortijas al bronce destinado para fundir campanas..."

Como la figura de aquel poema suyo en que el tigre va prendido del lomo del caballo, en fantástico galope por la selva, así la poesía de Chocano, perdido el control lógico, va sumergiéndose en una gradiosa maraña, guiado por fuerzas del instinto, sobre la que se perfila "alguna media luna roja", como enorme cuchillo levantado sobre la vida misma que corre hacia el acaso. Se diría la irregularidad de las odas pindáricas; pero el poeta dórico conocía las regularidades de su irregularidad y las maneajba con destreza; no perdiendo en la fronda lo que debía ser substantivo y fundamental. Hay en el Chocano épico un torrente continuo que no se detiene ni en los momentos en que busca el remanso. Las imágenes son para él la realidad misma y su inspiración es fuerte, excesivamente sensible. El propio Chocano se encarga de definir en multitud de poemas su posición ante la poesía: manifestar el mestizaje indo-español, dentro de una formalidad que responda a la fuerza del paisaje de América; ya en "Blasón" o en "Ava$\operatorname{tar}^{\prime \prime}$ se siente mitad Inca, mitad Conquistador:

"[Cuántas veces he nacido! CCuántas veces me he encarnado! Soy de América dos yeces y dos veces español.

Si poeta soy ahora, fui Virrey en el pasado, capitán por las Conquistas y Monarea por "el Sol".

Y es Yupanqui, Soto, Esquilache y, al final, poeta del Perú: "divino y sagrado". Decía en "Alma América": "Mi poesía es objetiva; Y. en tal sentido, sólo quiero ser POETA DE AMERICA". Para serlo sentíase llamado por el destino y exaltaba la importancia de su verso que era el fuego entregado por Prometeo a los hombres. Le resultaba el mundo estrecho para su poesía y el laurel de la gloria le brotaba de su propio pecho... La idea del superhombre alimentaba la filosofía desde las hermosas páginas de Nietzsche y, sobre el bien y el mal, se llamaba asimismo "artista" "pastor de multitudes, poeta sobre las cumbres de los Andes, violador de las costumbres para engendrar nuevas leyes. En Chocano predominaba, así, la intencionalidad y el individualismo. "Cantor de América", y de sí mismo, Chocano llegó a la poesía con un tropel de imágenes y un relámpago en cada una de ellas, en un mensaje efectivamente nuevo. Ventura García Calderón 
que estudiara especialmente al poeta y que ha dado tantos sutiles datos para su mejor conocimiento, repite unas frases de José Santos Chocano, con motivo del centeriario de Melgar, que son muestra cabal de su estilo y del motivo central de su obra: "El Perú que no conoce rivales en riqueza natural, -decía Chocano- merece bien por su importancia y grandeza históricas el nombre de Tebas de América. Ya la. Naturaleza, ya la Historia, ya nuestro modo de ser moral e intelectual pueden servir de Hipocrene para los poetas que, verdaderamente nacionales, cuelguen, como las águilas, sus nidos en los nevados picos de los Andes". Esto en 1891, aún estudiante. Desde entonces inició el camino de su lenguaje épico y centralizó toda la poesía peruana, en un espacioso momento de nuestra historia literaria.

Nació José Santos Chocano en Lima, el 14 de Mayo de 1875; de familias moqueguanas por el lado paterno y trujillanas por el materno, unificó dos tendencias tradicionales en el medio social del Perú. Sigamos, de rato en rato, a García Calderón en el esquema de su biografía. "Los juveniles ataques del escritor en "La Tunda" el violento periódico satírico de la época (1894) lo llevaron a los Aljibes y Casas Matas del Callao donde firma algunos versos de su primer libro". Son estas las "Iras Santas", cuando Chocano revisa a Luis Benjamín Cisneros, repite a Quintana, pero considera a Campoamor, su "Maestro", y a Víctor Hugo un ejemplo en su lucha contra Napoleón III:
"Mientras haya en laccúspide un tirano,
mientras haya en el antro un prisionero mientras en la ciudad quiera el guerrero hacer lo que en la breña y en el llano. mientras no se alce al Pueblo Soberano, yo, hecho Job de este inmundo estercolero, he de cantar las rabias que el acero siente al hallarse entre la puerca mano".

Persiste Chocano en la escuela romántica, trazando un programa de acción poética que debe tener como guía a Hugo quien "estranguió con mano hercúlea al paralítico clasícismo". García Calderón continúa: "En 1897 funda LA GRAN REVISTA y, a fines del mismo año, EL SIGLO XX. En 1901 el Perú lo envía a Centro América como agente de propaganda y Encargado de Negocios. Regresa a Lima y es nombrado en 1903, Secretario de primera clase, luego Encargado de Negocios, en 
Colombia. De 1905 a 1909 reside en Madrid como Secretario de nuestra Legación en España".

Es ien esta etapa en la que Chocano se alinea en el "modernismo", expresión propia de América y de España, donde surgen figuras en franca rebeldía contra la poesía romántica, pero alejadas, asimismo, de la prosa naturalista y del expresionismo poético. Chocano ha publicado ya "Selva Virgen", la imperfecta y monótona "Epopeya del Morro", las poesías líricas de "Azahares" y "En la Aldea", donde el descriptivismo va unido a una intensa emoción y culmina en "Alma América", el libro fundamental, epicéntrico de su obra. Lo subtitula: "Poemas indo-españoles"; y estampa motivos de nuestra geografía y nuestra historia, en una variedad polifónica, con la lectura acuciosa de la tradición, pero la mirada puesta en el futuro. En "Alma América" están los cóndores y las vicuñas, pero también Pizarro y la "limeña" de estirpe española; motivos costumbristas y profusión de panoramas de Lima, de los Andes, de las selvas... Sus conocidos trípticos. En "Alma América" exalta a Incas y Virreyes; a los pantanos, a las cataratas; canta con las panderetas españolas y se sumerge en una fícción de melancolía indígena, para levantar luego la voz llamando al "país del Amazonas" el "centro del mundo". En "Alma América" hace profesión de fé de su credo poético - "con majestad de Inca y orgullo de español" - y expresa que su estillo se quema en la fragua, donde se forjan las palabras fuertes: $Y$ ' buscaré Cofra musa quie asombre al Universo". "Jorge Puccinelli Converso"

Otra vez al esquema biográfico: "En 1909, en New York vive alejado de la carrera diplomáticà por razones que es bueno omitir" —dice Ventura García Calderón-- "No aspiro a ser ni bueno ni malo, sino artista" -. "Luego en Guatemala funda La Prensa. En México, en 1923, La Nueva Era. El junio del mismo año, es expulsado y lo reciben con aplauso en La Habana. Más tarde a Puerto Rico, cuyo Congreso lo ha invitado a dar una conferencia; vive en Nueva York como agente confidencial del Gobierno Revolucionario Mexicano de Carranza y de Pancho Villa. Secretario del mismo toma parte en la toma de Chihuahua. En 1919, es personaje central de la política guatemalteca y favorito del Presidente Estrada Cabrera. Al caer éste, estuvo a punto de ser fusilado". Intelectuales de España y América intervinieron entonces en favor de Chocano. Su personalidad literaria tenía ya categoría universal, Para entonces, no sólo él, sino figuras autorizadas de la crítica, lo llamaban el "Poeta de América". Dígalo si no la opinión de George Um- 
prey. Desde 1906 hasta 1919, Chocano había expurgado sus poemas juveniles románticos en la nueva edición completa de "Fiat Lux"; en México y en París habían publicado antologías de su obra: "Los Cantos del Pacífico", correspondientes a su primera etapa en los que ya se pronunciaba en contra del "arte por el arte"; y de su "Alma América", en nuevas selecciones de poesía. También había, en redondas frases expuesto teorías políticas que correspondían al tropicalismo de su "demonio lírico"; y los versos venían a corrobarar lo dicho en prosa:

"Para toda orfandad mi alma es un manto

y un firme escudo para todo pecho!..."

Habla contra el "lenguaraz tumulto" y expresa que compone versos para cantar a los "Héroes" y al "heroismo"; no para los partidarios del maquinismo, sino para los que escuchan la voz de la naturaleza misma; que está contra todo artificio, pues busca el "arte humano", "ya que su parte deben tener el corazón y el arte". Después avanza en su teoría de las "dictaduras organizadas", y se aleja definitivamente de la "multitud".

"En 1920 --continúa aquí García Calderón- reside en Costa Rica. Va a Lima en 1922 a ser coronado y asesina por un fútil pretexto, en el curso de una reyerta, al ya reputado escritor Edwin Elmore. Muere asesinado en Santiago del Chile (1934), donde residía colaborando en diarios chilenos y argentinosílcc Ene sú última etapa. Chocano, publica diversos poemas, en Lima, con motivo de su exaltación poética de 1922, y su "Poema de Ayacucho" en 1924; y luego edita en Chile "Primicias de Oro de Indias" y"Poemas del Amor Doliente". Preparaba una obra definitiva con el título de "Poemas Neo-Mundiales".

Como en el caso de Palma y de Prada, Chocano es una figura universalmente consagrada. La reacción antichocanista llevó durante largo espacio, sin embargo, a una detracción exagerada de ese indudable gran poeta que tiene por particularidades su impresionismo rutilante y su afán de encontrar la tonalidad que corresponda a una poesía americana que, como manifiesta en sus versos a Rubén Darío, fueran réplica de lo que expresa la Naturaleza: "el bosque grave, el lago suave, el volcán fuerte"... Jiménez Borja, ha dicho: "La adoración de la Naturaleza americana como una fuerza de fecundidad palpitante y maravillosamente eclosiva, tal como Chocano la sueña, hace que su manera de mirar sea la de un impresionista que amplifica los objetos y los revierte en 
un espejo de aguas tumultuosas. Piensa por imágenes, según la vieja definición de Goethe, y cada estrofa suya es una apretada acumulación de ellas con una abundancia de cornocupia renacentista. Conoce los secretos que producen tales imágenes sobre el ecran, y es hábil operador especialmente de la hipérbole y del símil, utilizando menos la metáfora". "Es rotundo y claro - añade líneas después - con una elocuencia que linda en el exceso verbal, pero con un permanente poder plástico y una limpidez de metal bruñido y preciso". Xammar, en su ensayo sobre "El Perú en la poesía de José Santos Chocano", delinea las características personales del poeta y se detiene en el acento lírico de sus primeros poemas, "versos nupciales llenos de dulce ternura", para luego ofrecer el contraste de sus fuertes poemas sobre la naturaleza peruana, recordando palabras de Rubén Darío sobre nuestro poeta: "vive de amor de América y de pasión de España", que Xammar revierte en su conclusión: "Gran señor de metáforas e imágenes, dominador de los más recónditos paraísos del verso y elocuente profeta de un futuro americano, pleno de fervorosa vitalidad, Chocano tiene el noble gesto de respetar su nexo con la cultura española. . En la escala de sus sentimientos rinde ascendrado culto a su pasión por el Perú, a su pasión por América y a su pasión por España. Pero no eran tres pasiones distintas como en el dogma cristiano, sino una sola y generosa pasión por la tierra YBporl la faza de este lado del mundo". "Fué sin saberlo a punto fijo y a pesar del medio que no acertó a comprenderlo (?), el poeta del Perúy y un cantor peruanísimo - dice extrañamente Ventura García Calderón. Creemos por el contrario, que Chocano encontró franca y jubilosa acogida popular, y que la resistencia contra él prendió en los círculos intelectuales.

Raúl Porras Barrenechea ha hecho una interesante vivisección de Chocano mostrándonos el valor de su producción. "El poeta en carne viva del Perú" lo llama, explicando "que podrá negársele sinceridad en muchos de sus versos, excesivos oropeles en la frase, pero no podrá arrebatársele la honda e infalsificable peruanidad de su estro". En el aspecto formal, Porras estudia su permanencia romántica por encima del parnasianismo o del modernismo y pone sobre el tapete "el ardor sensual de sus metáforas"; la metáfora suya, "chocanesca", que él encuentra "racionalizada", con "la frialdad de un silogismo" y que de pronto "salta repentinamente con un magnífico impulso vital, salvando el vértigo entre dos abismos conceptuales". Señala también Porras Barrenechea las tres direcciones de su poesía: la épica, ungida de "emoción 
histórica, verbal y tribunicia"; la bucólica, donde expande su "vigoroso poder descriptivo y de gran sensitivo dominador de todas las percepciones de olor, color y sonido"; y la tercera, la autobiográfica, que resalta unilateralmente Tauro en "Elementos de Literatura Peruana". Rubén Darío lo emparentaba a Garcilaso, pues encontraba que en Chocano "la civilización incaica se presentaba con la misma suntuosidad que ante la imaginación de Garcilaso"; y en cambio la crítica de Mariátegui, lo ubicaba en la poesía hispanista.

A Chocano le faltan meditación y trascendencia intelectual, pero es indudablemente uno de los grandes poetas de habla castellana, que vivió buscando, ciertamente, sonoros efectos declamatorios, pero que dió rienda suelta a una fanfasiosa imaginación y que vivió en acecho de una nota particular de la poesía: el trasunto de la naturaleza peruana y americana en general, dentro de una dionisiaca expresión particular.

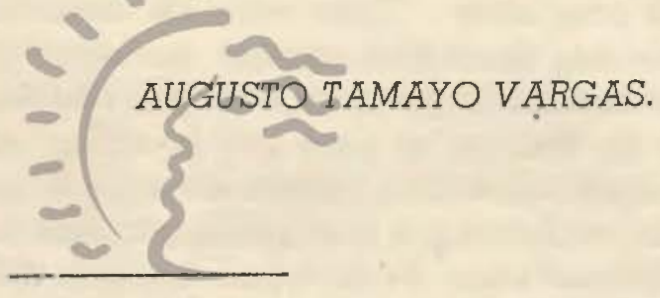

\section{Biblioteca de Letras} "Jorge Puccinelli Converso" 